Ekonomia i Zarządzanie

$\operatorname{IX}(4) / 2016$

ISSN 1896-8147

DOI: http://dx.doi.org/10.21784/EiZ.2016.024

WANDA GRYGLEWICZ-KACERKA

DANIEL SOLIWODA

Państwowa Wyższa Szkoła Zawodowa we Włocławku

\title{
Wpływ aplikacji mobilnych na wzrost bez- pieczeństwa podróżujących po górach
}

\section{Influence of mobile applications on the increase of Ravel security in the mountains}

\section{Streszczenie:}

W pracy zaprezentowano sposób w jaki aplikacje mobilne wspierają turystę w przygotowaniach do podróży po górach. Zaprezentowane zostały różne typy aplikacji, które w zależności od potrzeb wspierają podróżnych w ustaleniu zbliżającej się pogody bądź znalezieniu odpowiedniego miejsca do odpoczynku. Przedstawiony został również pomysł na aplikację monitorującą poczynania podróżnego na szlaku.

\section{Abstract:}

The paper presents the way how mobile applications support tourism in the preparation for traveling in the mountains. Various types of applications were presented. Their task is to support the user. They help in predicting the weather. The idea was also presented for an application monitoring the journey of the traveler on the trail.

Słowa kluczowe: aplikacja mobilna, bezpieczeństwo, góry

Key words: mobile applications, protection, mountains 


\section{Wprowadzenie}

Każdy kto pasjonuje się wyprawami górskimi zdaję sobie sprawę, że przed wyruszeniem na trasę należy prawidłowo przygotować się. Specjaliści (na czele z ratownikami GOPR/TOPR) doradzają aby dokładnie zaplanować wszystkie etapy wędrówki po górach. Na oficjalnej stronie Górskiego Ochotniczego Pogotowia Ratunkowego znajdziemy precyzyjne informacje jak należy to zrobić. Do najbardziej istotnych zalicza się :

- - określenie przebiegu szlaku turystycznego, którym będziemy się kierować,

- - prześledzenie sieci schronisk turystycznych,

- $\quad$ obliczenie czasu marszu od momentu wyjścia aż do punktu docelowego,

- - przeanalizowanie obszaru podróży pod kątem obiektów, które mogą stanowić awaryjne schronienie na szlaku w przypadku załamania się pogody,

- - określenie wysokości nad poziomem morza na jaką będziemy musieli podejść oraz różnice wzniesień na podejściach i zejściach w czasie wędrówki.

Na potrzeby tego zadania komponowane są obecnie różne przydatne aplikacje mobilne. Mają one dostarczyć turyście (użytkownikowi) niezbędnych informacji na temat możliwych tras do przejścia, warunków pogodowych oraz potencjalnych zagrożeń, na które wędrujący może się natknąć w trakcie swej podróży. Obecnie kiedy technologia jest już wysoko rozwinięta - standardowe mapy papierowe są zastępowane przez małe, podręczne urządzenia mobilne. Zawierają one najczęściej wiele przydatnych danych do których dostęp jest możliwie szybki (telefony mobilne).

\section{Zasady tworzenia aplikacji mobilnych}

Do zalet aplikacji mobilnych zalicza się ich szybkość. W przeciwieństwie do aplikacji uruchamianych $\mathrm{w}$ przeglądarce urządzenia, standardowe aplikacje mobilne nie wymagają użycia dodatkowego programu, który odpowiadałby za ich funkcjonowanie i byłby ich "gospodarzem".

Dodatkowym atutem jest zastosowanie natywnego kodu, który bezpośrednio integruje się z kodem platformy wykonawczej co pozwala na zoptymalizo- 
wanie pracy programu oraz zmniejszenie zapotrzebowania na zasoby sprzętu. Zaoszczędzoną dzięki temu moc można wykorzystać do rozbudowy aplikacji o dodatkowe funkcjonalności.

Oprócz natywnego kodu dodatkowym atutem pracy z aplikacjami mobilnymi jest możliwość pracy w trybie offline (nie wszystkie aplikacje wymagają dostępu do Internetu). W przypadku przeglądarek aby skorzystać z informacji na określonej stronie internetowej wymagane jest połączenie sieciowe (o ile nie korzystamy ze serwera/bazy danych wbudowanego w urządzenie). Dodatkowo bardzo ciekawym rozwiązaniem okazuje się wykorzystanie elementów sprzętowych będących częścią urządzenia. Odczytywanie danych z zainstalowanych układów mierniczych takich jak: GPS, Akcelerometr, pozwala przekształcić prostą aplikację mobilną w narzędzie do pomiaru przyspieszenia bądź oszacowania aktualnej lokalizacji użytkownika.

Wielu ekspertów w dziedzinie projektowania aplikacji na urządzenia mobilne zwraca szczególną uwagę na konieczność precyzyjnego projektowania elementów graficznego interfejsu użytkownika. Zaprojektowane elementy graficzne powinny być dopasowane do platformy, która wspiera budowaną aplikację.

Aktualnie istnieje wiele narzędzi umożliwiających projektowanie i programowanie aplikacji mobilnych. Za najważniejsze obecnie środowiska programistyczne uznaję się: Android Studio, Xcode oraz VisualStudio (oferuje dodatkowo moduł Xamarin tworzenie aplikacji hybrydowych).

Zebrawszy wszystkie dotychczas poznane informacje, warto wykonać rozeznanie wśród już istniejący aplikacji i dostosować własny wzorzec do panujących trendów.

\section{Przegląd dostępnych aplikacji wspomagających turystów górskich}

Wśród wielu oferowanych aplikacji mobilnych można wyodrębnić trzy standardowe grupy:

- aplikacje wyposażone w mapy turystyczne (papierowe i firmy Google - Google Maps),

- aplikacje dostosowane do wyszukiwania atrakcji turystycznych,

- narzędzia pomocnicze, które dostarczają szczegółowych informacji o warunkach na szlakach turystycznych. 
Aplikacja Google Maps wyposażona jest ostatnio w tryb Google Street View. Mapy Google posiadają bardzo dobrej jakości zdjęcia satelitarne oraz bazę przydatnych komercyjnych miejsc.

Aplikacja MAPS.ME (bazując na mapach projektu OpenStreetMap) oferuje użytkownikom precyzyjne mapy uzupełnione o drogi gruntowe oraz ścieżki leśne. Dodatkowym atutem tej aplikacji jest możliwość wczytania jej do pamięci urządzenia co sprawia, że aplikacja może pracować bez Internetu. Aplikacja jest prosta w obsłudze.

Aplikacja Polska Niezwykła została ona wyposażona w przewodniki tematyczne po wybranych rejonach kraju.

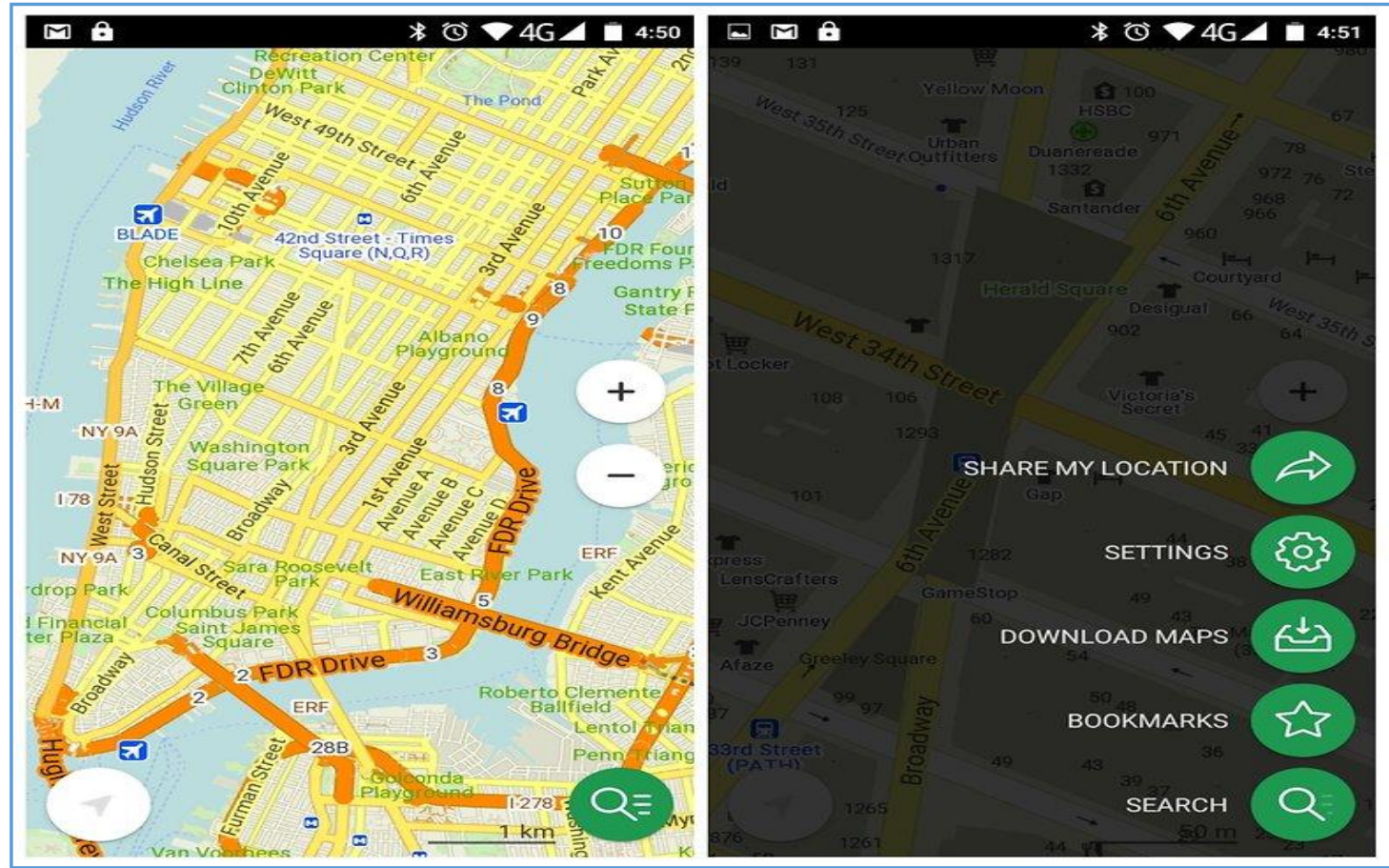

Rysunek 1. Widok aplikacji MAPS.ME [1] 


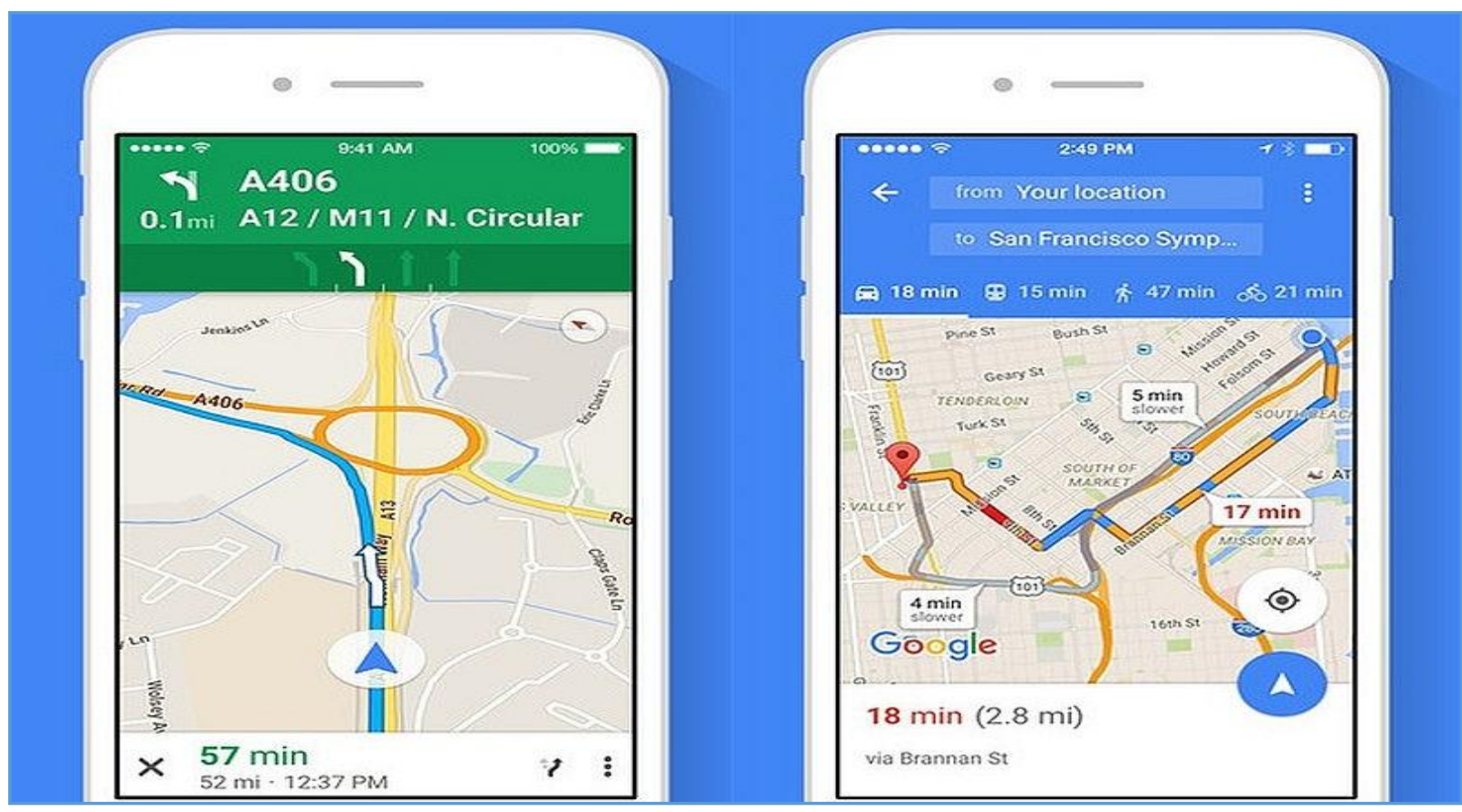

\section{Rysunek 2. Widok aplikacji Google Maps [2]}

Ponad to każda osoba, która dokona rejestracji na stronie: http://www.polskaniezwykla.pl/ może zamieścić własny komentarz przy wybranym przez siebie obiekcie.

Aplikacja Elomaps pozwala użytkownikom umieszczać swoje opisy oraz opinie dotyczące odwiedzonych miejsc. Elomaps lokalizuje ciekawe miejsca w postaci punktów POI na warstwie Google Maps. Aplikacja posiada również sortowanie obiektów względem ich popularności przez co pozwala zaplanować kolejność odwiedzanych miejsc. 


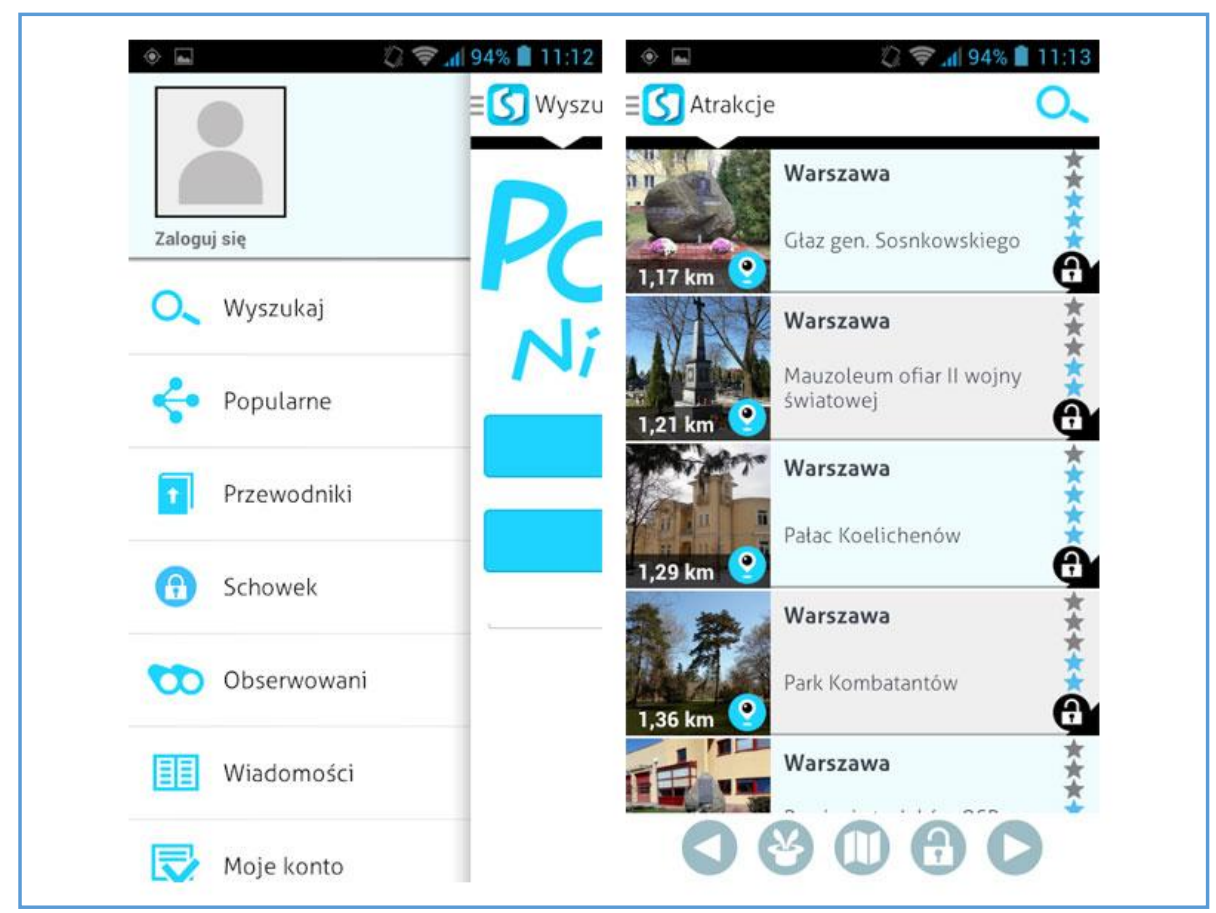

\section{Rysunek 3. Widok aplikacji Polska Niezwykła [3]}

Aplikacja Meteo ICM to doskonałe narzędzie wspierające turystę w określeniu warunków pogodowych panujących na trasie (prognoza pogody na najbliższe dni).

Aplikacja RATUNEK umożliwia poprzez trzykrotne naciśnięcie przycisku ratunkowego, kontakt z TOPR/GOPR lub WOPR/MOPR. Do prawidłowego funkcjonowania wymagany jest sprzęt wspierający technologię GPS oraz posiadający aktualną umowę z operatorem telefonii komórkowej. 


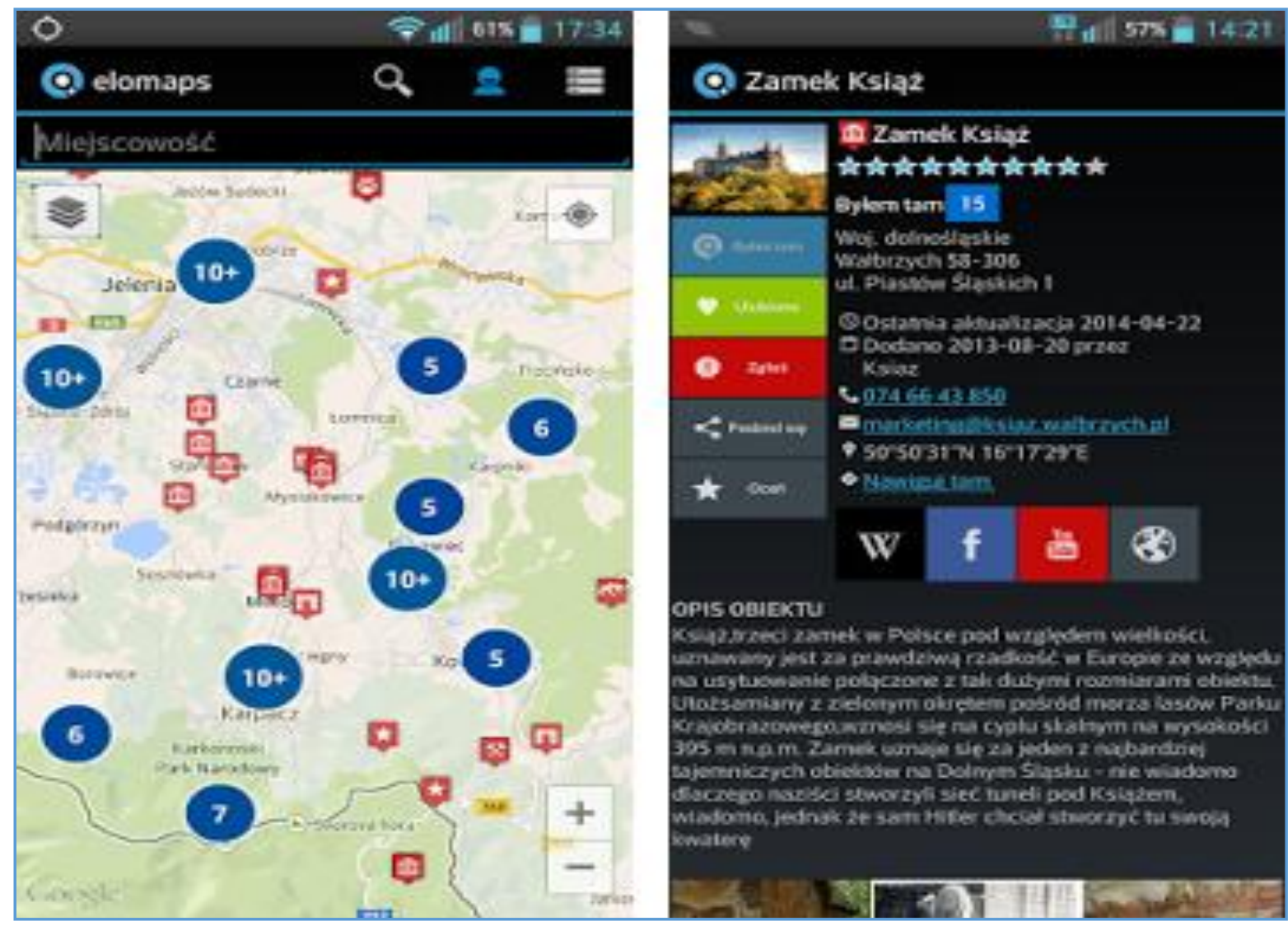

\section{Rysunek 4. Widok aplikacji Elomaps [4]}

Jest to wymóg konieczny, gdyż zapobiega nieumyślnym lub fałszywym zgłoszeniom. Oprócz funkcji komunikacyjnych aplikacja posiada wbudowaną książeczkę medyczną, która dostarcza informacji na temat obecnego stanu zdrowia. Warto dodać, że aplikacja prócz zgłoszenia telefonicznego przesyła w formie wiadomości sms współrzędne lokalizacji osoby poszkodowanej. 
Podsumowując Ratunek to dobre narzędzie komunikacyjno-ratownicze, które sprawdza się w sytuacjach, w których użytkownik jest samodzielnie w stanie wezwać pomoc.

\section{Aplikacja Bezpieczny turysta - (opracowanie własne)}

Często jednak bywa tak, że na skutek wypadku i odniesionych obrażeń, osoba poszkodowana nie posiada takiej możliwości zawiadomienia kogokolwiek. Jest to problem, który spowodował zaprogramowanie aplikacji monitorującej zachowanie turysty na szlaku. Nazwa aplikacji: Bezpieczny turysta. Przegląd dostępnych aplikacji wspomagających turystę w górach wykazał, że brakuje aplikacji, której zadaniem byłoby monitorowanie postępów podróży oraz czynności wykonywanych poza obszarem schronisk górskich. Tak powstał projekt aplikacji mobilnej wyposażonej w GPS. Projekt został wykonany z użyciem systemu Android.

5. Instrukcja obsługi aplikacji Bezpieczny turysta - (opracowanie własne)

Po uruchomieniu aplikacji na smartfonie ujrzymy okno logowania. Jako tło ustawiony został widok górski co jednoznacznie określa charakter aplikacji.

\section{Okno logowania}

W górnym lewym rogu na tle nieba umieszczone zostało logo aplikacji, które jest znakiem rozpoznawczym programu. Drogowskaz z napisem "Loguj" wyzwala procedurę logowania do aplikacji. Weryfikacja danych odbywa się po przez odpytanie zewnętrznej bazy danych o istnienie użytkownika opisanego danymi zawartymi w polu Login i Password. W przypadku wprowadzenia niepoprawnych danych wyświetlany jest krótki komunikat "Niepoprawne dane". W sytuacji gdy nie wprowadzono żadnych informacji wyświetlony zostaje komunikat z prośbą o wprowadzenie wymaganych informacji. Aby zabezpieczyć cały proces logowania przed niechcianym przejęciem danych, całość odbywa się przy pomocy procedury bazodanowej zwracającej prawdę - gdy użytkownik istnieje lub fałsz gdy wywoływanego użytkownika nie ma $w$ bazie.

\section{Rejestracja nowego użytkownika}

Okno logowania umożliwia również zarejestrowanie się użytkownika w przypadku nie posiadania konta w serwisie. W tym celu należy kliknąć na 
ikonę z potrójnymi kropkami w górnym prawym rogu i wybrać opcję rejestruj.

Po potwierdzeniu komunikatu o chęci zarejestrowania się do systemu przeniesieni zostajemy do okna rejestracji. Uzupełniając wszystkie pola oraz zatwierdzając chęć rejestracji przyciskiem dodajemy nowego użytkownika do bazy. Układ wszystkich elementów regulowany jest przez plik XML, który zawiera style wizualne wspierane przez system android.

Najchętniej wykorzystywany jest LinearLayout, który szereguje elementy w sposób wertykalny bądź horyzontalny.

\section{Okno główne - dostępne opcje}

Po przejściu do okna głównego aplikacji zauważymy panel z czteroma zakładkami, które kolejno dotyczą trybów/ustawień, dostępnych akcji, map i aktualnych informacji o tatrzańskich górach. Poruszanie się po owym panelu może odbywać się na dwa sposoby.

- W pierwszym wystarczy nacisnąć chcianą zakładkę i automatycznie zostaniemy do niej przeniesieni.

- Drugi sposób to przesunięcia palcem po wyświetlaczu, która to czynność będzie nas przełączać pomiędzy poszczególnymi zakładkami.
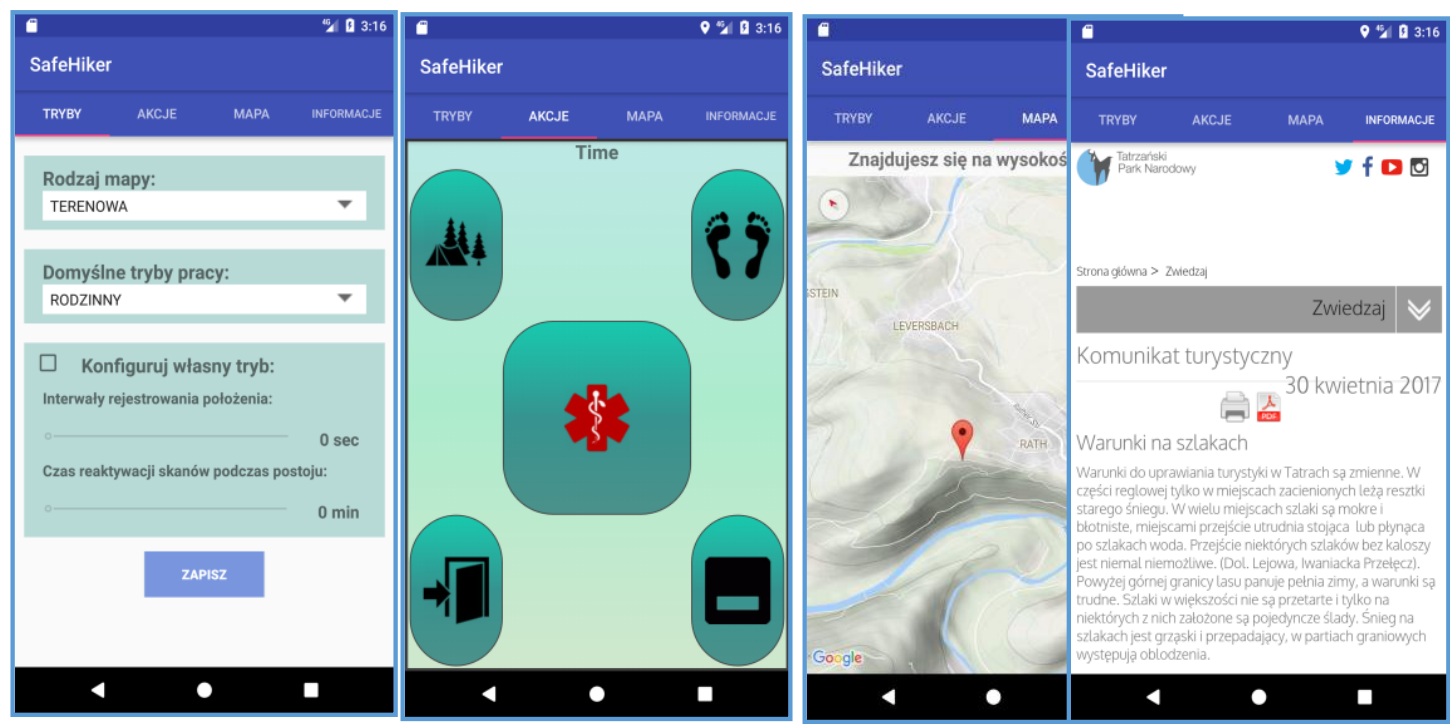


\section{Rysunek 5. Wybrane fragmenty aplikacji mobilnej Bezpieczny turysta (źródło: Opracowanie własne)}

Pierwsza zakładka - dotyczy personalizacji ustawień. Przy pomocy dostępnych opcji konfigurujemy tryb pracy aplikacji oraz wybieramy rodzaj mapy. Aplikacja została wyposażona w trzy domyślne tryby : Rodzinny, Krajoznawczy, Samotna Wyprawa. Każdy z nich charakteryzuje się własnym zestawem danych, które określają interwały rejestrowania położenia oraz czas reaktywacji skanów podczas postoju. Aby nie ograniczać użytkownika zaimplementowano dodatkowe pole $\mathrm{z}$ możliwością ręcznej konfiguracji tych parametrów. Dodam, że każdy z tych parametrów jest przeliczany w języku programowania na milisekundy. Pole $\mathrm{z}$ wyborem typu mapy zostało wyposażone $\mathrm{w}$ cztery opcje: terenowa, satelitarna, hybrydowa, standardowa. Każda z nich wizualnie dostosowuje mapę do aktualnych potrzeb użytkownika. Przykładowo mapa terenowa uwzględnia ukształtowanie terenu oraz wyposażona jest w poziomice określające aktualną wysokość nad poziomem morza. Aby ustawienia zostały zapisane należy kliknąć przycisk 'Zapisz'. Jeśli zapis będzie udany ujrzymy komunikat- "Zapisano ustawienia". Od tej pory domyślne ustawienia zostaną zastąpione własnymi.

Druga zakładka - zawiera aktualne informacje dotyczące warunków pogodowych. Ta zakładka wykorzystuje element WebView, którego zadaniem jest wyświetlanie pojedynczych stron internetowych w aplikacji mobilnej. Została zaimplementowana do projektu oficjalna strona Tatrzańskiego Ochotniczego Pogotowia Ratunkowego z komunikatami dla turystów. Wybór tej strony był oczywisty ze względu na stałą aktualizację informacji oraz związek z polskimi Tatrami. W wyświetlanych komunikatach możemy odnaleźć informacje na temat warunków pogodowych oraz zagrożeń panujących na szlakach.

Trzecia zakładka - została wyposażona w najnowszą wersję Map Google. Po włączeniu rejestrowania położenia, (o co zostaniemy poproszeni przy ładowaniu map), wyświetlona zostanie aktualna lokalizacja użytkownika w postaci czerwonego markera. Jego położenie na mapie będzie uzależnione od ostatnio zarejestrowanych parametrów.

Dodatkowo Map Google umożliwia uruchomienie nawigacji GPS, która poprowadzi turystę do wskazanego miejsca oraz określi dystans i czas wę- 
drówki. W celach informacyjnych nad mapą został umieszczony element TextView, który prezentuje aktualną wysokość n.p.m określoną przez GPS. Czwarta zakładka - obsługuje automatyzację procesów monitorowania wędrówki oraz wzywania pomocy. Okno jest wyposażone w pięć przycisków z przypisanymi im zadaniami:

Przycisk z wizerunkiem otwartych drzwi umożliwia opuszczenie aplikacji i automatycznie dezaktywuje usługę - Lokalizacja.

Przycisk z wizerunkiem panelu min odpowiada za oczyszczenie lokalnej bazy danych SQLite. Baza ta przechowuje informacje na temat użytkownika (login) oraz historię przebytej drogi w postaci parametrów geo-lokalizacyjnych zapisywanych cyklicznie w określonych przez ustawienia odstępach czasu. Jej systematyczne czyszczenie poprawia stabilność pracy aplikacji.

Przycisk z ikonq stóp uruchamia procesy monitorowania (uruchamiane są wątki odpowiedzialne za cykliczne powtarzanie akcji). W ramach tych akcji dokonywany jest zapis i odczyt danych z lokalnej bazy oraz wykonywany jest odczyt pomiarów z modułów GPS i akcelerometru. W następnej kolejności pozyskane informacje są przetwarzane i na bazie wyników system decyduje o konieczności wysłania zgłoszenia.

Bodźcem decydujący o wysłaniu alertu do systemu administracyjnego jest stwierdzenie, że urządzenie znajduje się w stanie spoczynku przez dłuższy czas będąc jednocześnie w trybie monitorowania. Sytuacja ta symuluje zdarzenie, w którym osoba poszkodowana na skutek odniesionych obrażeń traci przytomność i tym samym przebywa w bezruchu co uniemożliwia wezwanie pomocy. Wykorzystanie odczytów z dwóch dostępnych modułów pozwala na dokładniejsze zinterpretowanie zaistniałej sytuacji. Jeśli właściciel urządzenia nie jest w ruchu a zatem jego przyspieszenie jest zerowe, w dwóch najbliższych skanach sytuacja ta zostanie zarejestrowana. Po przeanalizowaniu otrzymanych danych system na wyświetlaczu urządzenia wyświetli komunikat ostrzegawczy wraz z towarzyszącym mu sygnałem dźwiękowym. Brak odpowiedzi zwrotnej spowoduje jego zamknięcie oraz wysłanie zgłoszenia do bazy administrującej systemu. Będzie ono zawierało ostatnie zarejestrowane położenie. Potwierdzeniem wysłania zgłoszenia będzie informacja znajdująca się na górze okna oraz migający na czerwono środkowy przycisk interfejsu.

W przypadku gdy chcemy na określony czas wyłączyć monitorowanie, musimy posłużyć się przyciskiem z wizerunkiem namiotu. Interakcja z przyciskiem spowoduje dodatkowo inicjalizację wątku mierzącego czas przerwy. 
Po upływie dostępnego czasu otrzymamy informację dotyczącą wznowienia skanowania lub przedłużenia postoju. W zależności od wybranej opcji system wznawia swoje działanie albo zawiesza je na kolejne 15 min.

Przycisk $z$ wizerunkiem gwiazdy życia pozwala na możliwość własnoręcznego kontaktu z panelem administracyjnym systemu. Potrójne kliknięcie zabezpieczające przed niechcianym wezwaniem pomocy spowoduje wysłanie zgłoszenia do centrali obsługującej system. Jest to opcja umożliwiająca szybką reakcję w sytuacji zagrożenia życia bez konieczności oczekiwania na kolejne skanowania dokonywane przez system. Funkcja wskazana w momencie kiedy osoba poszkodowana jest w stanie o własnych siłach wezwać pomoc.

\section{Zakończenie oraz wnioski}

Zaproponowana aplikacja do dobry "partner" do wędrówek podczas, których należy mieć wyostrzoną czujność. Góry, choć piękne, bywają zdradliwe. System zaprojektowany jest systemem rozwojowym, można go rozbudowywać dowolnie.

System został wyposażony w wiele udogodnień i tak zaprojektowany aby mógłby być dowolnie rozbudowywany.

Aktualnie przeprowadzone testy oprogramowania wykazały drobne brakujące opcje tej aplikacji. Przykładowo gdy wyślemy niechciane zgłoszenie (nie odpowiemy na komunikat ostrzegawczy albo zagubimy telefon). Taki awaryjny przypadek trzeba rozwiązać w oparciu o np. zdalny pomiar tętna użytkownika. Dane tego pomiaru należałoby przesłać do bazy monitorującej wyprawę.

Istnieje jeszcze wiele nie rozpatrzonych przypadków awarii. Intensywne badania i rozwijanie aplikacji Bezpieczny turysta może chronić życie turystów.

\section{Bibliografia:}

[1] Źródło: https://www.androidpit.com/best-free-offline-map-apps.

[2] Źródło: http://gadgets.ndtv.com/apps/news/google-maps-for-iosnow-lets-you-add-pit-stops-gets-3d-touch-support-808437.

[3] Źródło: http://dziennikturystyczny.pl/2014/08/polska-niezwykla/.

[4] Źródło: http://www.apkmonk.com/app/elomaps.com/.

[5] Wskazówki dla turystów, https://www.gopr.pl/poradnik/wskazowki-dla-turystow. 
[6] Tworzenie własnej aplikacji na androida, https://majsterkowo.pl/tworzenie-wlasnej aplikacji-na-androida/.

[7] Grzegorz Róg, Projektowanie aplikacji mobilnych - Co musisz wiedzieć?, http://blog.eduweb.pl/projektowanie-aplikacjimobilnych-co-musisz-wiedziec-jak-zaczac/.

[8] Aktualności z tatrzańskich gór, http://tatromaniak.pl/aktualnosci. 